\title{
34. PETROGRAPHY AND PETROCHEMISTRY OF MIOCENE VOLCANICLASTIC SANDSTONES (HOLE 397)
}

\author{
B. G. Lopatin, Research Institute of the Geology of the Arctic Scientific Technical Complex SEVMORGEO, \\ Leningrad, USSR
}

\section{INTRODUCTION}

Volcaniclastic sandstones were recovered in the interval from 752 to 812 meters, from a middle Miocene turbidite sequence. We studied thin sections from 15 samples of volcaniclastic sandstones and determined clay mineral composition using X-ray diffraction of the fraction $<0.005 \mathrm{~mm}$ in 6 samples. Two phenocrysts of clinopyroxene and plagioclase were subjected to microsound analysis on MS-46, and one basalt fragment was subjected to quantitative spectroscopic analysis to determine chemical composition. Stratigraphic positions of the samples studied are plotted in Figure 1.

We divided the volcaniclastic sandstones into three units. The thickness and position of boundaries are uncertain, except for the uppermost one, because of poor core recovery.

\section{LITHOLOGY AND PETROGRAPHY}

Unit 1, at the base of the volcaniclastic sequence, consists of poorly layered and sorted dark gray medium-sized sandstones (Samples 85-3, 62-66 cm; 85-3, $26-28 \mathrm{~cm} ; 84-4,3-6 \mathrm{~cm}$; and $84-2,37-43 \mathrm{~cm}$ ). The predominant grain size varies from 0.5 to $1.0 \mathrm{~mm}$. The lower contact of this unit with marly limestone is distinct, but the upper boundary of the unit is unknown because of a gap in core recovery. Several thin layers of marly limestones and calcareous mudstones occur within the unit.

Fragments of volcanic origin make up about 55 per cent of the whole rock samples of this unit. They consist mainly ( 35 to $40 \%$ ) of completely altered vesicular brownish green glass shards. The vesicles are filled by microflaky brownish green chlorite aggregates and common zeolites with montmorillonite along the walls.

Minor constituents of the volcanic fragments ( 5 to $10 \%)$ are hyalobasalts with chlorite and iron oxides as a groundmass, and clinopyroxene-plagioclase basalts with holocrystalline microdolerite groundmass. The phenocrysts are represented by brownish, at times zoned augite having poor pleochroism, and infrequent platy calcic plagioclase. Holocrystalline groundmass is composed of minute (about 0.05 to $0.08 \mathrm{~mm}$ ) euhedral and irregular grains of augite, plagioclase and smaller isometric grains of opaques (magnetite?), and apatite needles. Augite is usually fresh and sometimes partly carbonatized, but plagioclase is altered. Augites, as separate fragments, are similar to those in phenocrysts.
Among mineral and rock fragments of non-volcanic origin, we noted angular to well-rounded grains of quartz, nannofossil-limestones, calcite, subordinate feldspar, and broken foraminifer and pelecypod tests.

The heavy fraction of the 0.05 to $0.1 \mathrm{~mm}$ size fraction consists of clinopyroxene $(76 \%)$, opaques $(12 \%)$, iron hydroxides $(3 \%)$, and pyrite $(3 \%)$. The rest is common hornblende, epidote, garnet, sphene, zircon, and leucoxene.

The cementing material is mainly montmorillonite with subordinate illite, chlorite, and kaolinite (Table 1). Throughout the volcaniclastic sandstone sequence, the clay mineral composition is uniform. Within the clay mineral matrix, zeolite and carbonate material occur.

Unit 2 is represented by fragments in Cores 81 and 80 (Samples 81-1, 32-37 cm; 81-1, 1-5 cm; 80-3, 61-66 $\mathrm{cm})$. The position of its lower boundary is unknown. It is separated from Unit 3 by a 2 -meter bed of blue-gray muddy quartz-foraminiferal fine-grained sandstone. Units 1 and 2 are similar in texture, structure, and color of volcaniclastic sandstones. But the proportion of glass shards and basalt fragments differ. In Unit 2 the glass shard content diminished to 25 per cent whereas the basalt fragment content increased to 25 per cent.

In Unit 2, vesicular volcanic glass is entirely altered into green chlorite-montmorillonite aggregates. These typically have a spheroidal structure made visibly by iron oxide dust. The vesicles are filled by flaky aggregates of chlorite and montmorillonite which serve as cementing agent. In the heavy mineral fraction (Sample $81-1,32-37 \mathrm{~cm}$ ), pyrite $(55 \%)$ and clinopyroxene $(40 \%)$ dominate. Additional heavy minerals are the same as those in Unit 1.

Unit 3 has a thickness of 8.2 meters and spans from Sections $80-1$ to $79-2$. This unit differs from previous ones by a lack of bedding, very poor sorting and in having a coarse-grained texture. Fragments from 2 to 5 $\mathrm{mm}$ predominate with some volcanic pebbles of 10 to $15 \mathrm{~mm}$ and individual limestone pebbles up to $5 \mathrm{~cm}$ in diameter. At the top of the unit (Section 79-2) volcaniclastic conglomerate grades into sandstone with predominant grain size of 1 to $2 \mathrm{~mm}$. The lower contact with fine-grained quartz-foraminiferal sandstone and the upper contact with mudstone are distinct and sharp.

The amount of volcanic rocks and mineral fragments reaches 60 per cent, whereas non-volcanic fragments make up about 15 per cent of the rock; the re- 


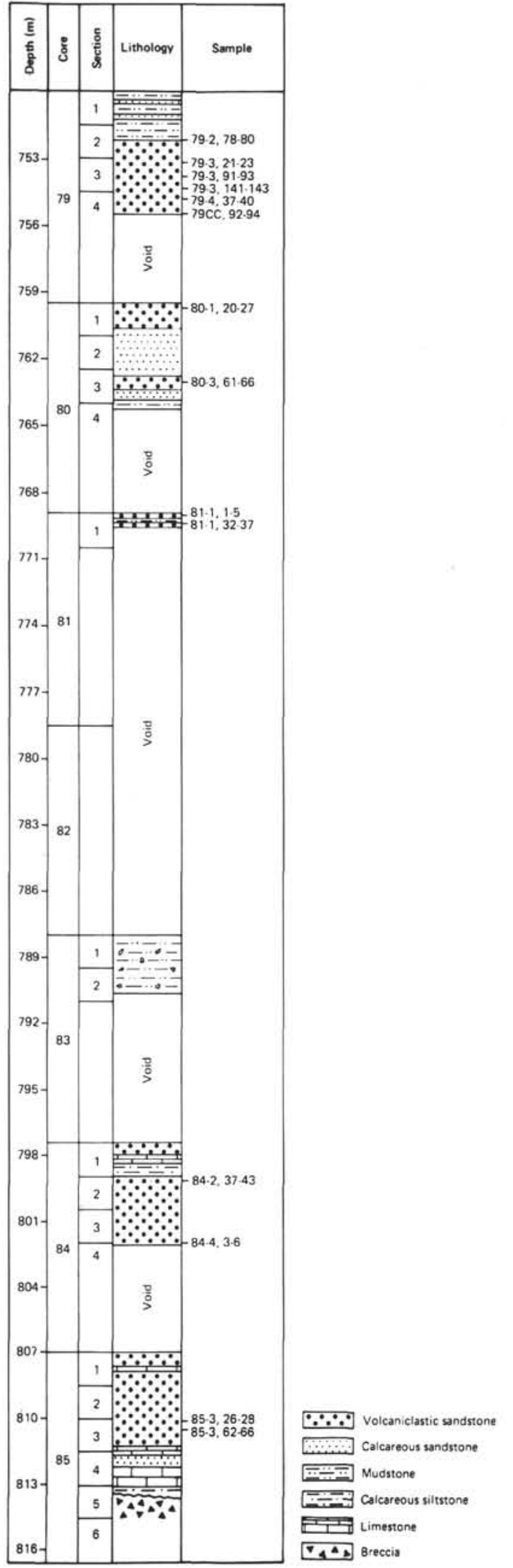

Figure 1. Position of the samples of volcaniclastic sandstones. $\quad 1$ = volcaniclastic sandstone; 2 = fine-grained quartz-calcareous sandstone; $3=$ mudstone; $4=\mathrm{cal}$ careous siltstone; 5 = limestone, 6 = breccia.
TABLE 1

Composition of Clay Minerals (wt. \%) From Hole 397

\begin{tabular}{c|cccc}
\hline $\begin{array}{c}\text { Sample } \\
\text { (Interval in cm) }\end{array}$ & Illite & Chlorite & Montmorillonite & Kaolinite \\
\hline $85-3,62-66$ & 10 & 5 & 80 & 5 \\
$80-3,61-66$ & 15 & 5 & 70 & 10 \\
$79-2,78-80$ & 10 & 5 & 75 & 10 \\
$80-1,20-27$ & 15 & 5 & 70 & 10 \\
$79-4,37-40$ & 10 & 5 & 75 & 10 \\
$81-1,32-37$ & 10 & 5 & 80 & 5 \\
\hline
\end{tabular}

Note: X-ray analysis on diffractometer DRON-1 conducted by V. N. Gerasimov, Research Institute of the Geology of the Arctic, Leningrad.

mainder is a microflaky brown-green matrix. Vesicular glass shards are wholly altered into green chloritemontmorillonite aggregate with spheroidal structure, as in the previous units.

Hyalobasalts and holocrystalline basalts occur roughly in equal proportions (15 to 20\%). Pyroxene-plagioclase holocrystalline basalts as the most common rock fragments have a microdolerite, pilotaxitic, sometimes trachytoid texture for the groundmass. The phenocrysts are represented by euhedral or corroded brownish zoned augite up to $3.0 \mathrm{~mm}$ and subordinate tabular plagioclase. Augite is usually fresh, whereas plagioclase is strongly altered. In one basalt fragment (Sample $79-4,37-40 \mathrm{~cm}$ ) we noted a serpentine-chlorite aggregate which likely is a pseudomorph after olivine phenocrysts. The groundmass consists of plagioclase latches (55 to $60 \%$ ), isometric grains of pyroxene (20 to $25 \%$ ), opaques and iron oxides (15 to $20 \%$ ), and apatite needles (about 1\%). The grain size of the groundmass does not exceed $0.1 \mathrm{~mm}$. Plagioclase lathes are sometimes oriented.

Vitrophyric basalts have hyalopilitic and microlitic groundmass texture. Clinopyroxene and calcic plagioclase phenocrysts are scarce. We did not note any fresh glass in the groundmass. It may have completely altered into aggregates of flaky minerals, iron oxides, and carbonate. Plagioclase microlites are also strongly altered. They sometimes show indistinct orientation. In amygdaloidal varieties of basalts, voids are partly or wholly filled by zeolites (Sample 79-4, 37-40 cm).

The heavy mineral fraction consists of clinopyroxene having the same appearance as phenocrysts (65 to $80 \%$ ), opaques (up to $15 \%$ ), pyrite (up to $12 \%$ ), and minor common hornblende, basaltic hornblende, epidote, garnet, zircon, sphene, spinel, biotite, and prehnite.

Non-volcanic fragments are represented by quartz, limestone, feldspar, and foraminifer tests.

Cement consists mainly of montmorillonite (Table 1). In addition to clay minerals, we noted carbonate and zeolite in voids and as rims around fragments.

\section{PETROCHEMISTRY}

We analyzed one fresh fragment of a typical holocrystalline pyroxene-plagioclase basalt (Table 2). Its chemical composition is that of slightly undersaturated trachybasalt. 
TABLE 2

Major Elements Analysis of Basalt Fragment (wt. \%) From Hole 397

\begin{tabular}{c|cccccccccc}
\hline $\begin{array}{c}\text { Sample } \\
\text { Interval in cm) }\end{array}$ & $\mathrm{SiO}_{2}$ & $\mathrm{TiO}_{2}$ & $\mathrm{Al}_{2} \mathrm{O}_{3}$ & $\begin{array}{c}\mathrm{FeO} \\
\text { Total }\end{array}$ & $\mathrm{MgO}$ & $\mathrm{MnO}$ & $\mathrm{CaO}$ & $\mathrm{Na}_{2} \mathrm{O}$ & $\mathrm{K}_{2} \mathrm{O}$ & Total \\
\hline $79-3,91-93$ & 50.0 & 3.8 & 11.2 & 11.07 & 8.6 & 0.43 & 7.7 & 2.9 & 2.6 & 98.30 \\
\hline
\end{tabular}

Note: Quantitive spectroscopic analysis conducted by L. M. Lopatina, Research Institute of the Geology of the Arctic, Leningrad.

TABLE 3

Major Elements Analysis of Clinopyroxene and Plagioclase From Hole 397

\begin{tabular}{|c|c|c|c|c|c|}
\hline \multirow[b]{3}{*}{ Oxides } & \multicolumn{2}{|c|}{ Clinopyroxene } & & \multicolumn{2}{|c|}{ Plagioclase } \\
\hline & $80-1,20-27$ & $80-1,20-27$ & & $79-2,78-80$ & $79-2,78-80$ \\
\hline & $1^{a}$ & $2^{b}$ & & $3^{c}$ & $4^{d}$ \\
\hline $\mathrm{SiO}_{2}$ & 46.69 & 52.20 & & 52.66 & 52.01 \\
\hline $\mathrm{TiO}_{2}$ & 2.61 & 0.71 & & - & - \\
\hline $\mathrm{Al}_{2} \mathrm{O}_{3}$ & 4.63 & 1.30 & & 27.55 & 27.13 \\
\hline $\mathrm{FeO}$ & 6.57 & 3.94 & & 0.78 & 0.77 \\
\hline $\mathrm{MgO}$ & 15.22 & 18.67 & & - & - \\
\hline $\mathrm{MnO}$ & 0.27 & 0.26 & & 0.15 & 0.12 \\
\hline $\mathrm{CaO}$ & 20.62 & 20.73 & & 10.37 & 10.11 \\
\hline $\mathrm{Na}_{2} \mathrm{O}$ & 0.60 & 0.47 & & 4.98 & 5.03 \\
\hline $\mathrm{K}_{2} \mathrm{O}$ & - & - & & 0.48 & 0.51 \\
\hline Total & 97.21 & 98.27 & & 96.96 & 94.67 \\
\hline Wo & 43.7 & 41.9 & $\mathrm{An}$ & 52.0 & 51.0 \\
\hline En & 45.3 & 52.0 & $\mathrm{Ab}$ & 45.0 & 46.1 \\
\hline Fs & 11.0 & 6.1 & Or & 3.0 & 2.9 \\
\hline
\end{tabular}

Note: Microsounding analysis on MS-46 conducted by A. G. Sysoev, All Union Geological Institute, Leningrad.

${ }^{\mathrm{a}}\left(\mathrm{Ca}_{0.83}{ }^{\mathrm{Na}} 0.04\right)_{0.87} \quad\left(\mathrm{Mg}_{0.86}{ }^{\mathrm{Fe}}{ }_{0.21} \mathrm{Mn}_{0.01}{ }^{\mathrm{Ti}} 0.05\right)_{1.13} \quad\left(\mathrm{Ti}_{0.02}\right.$ $\left.\left.\mathrm{Si}_{1.77} \mathrm{Al}_{0.21}\right)_{2.00}\right)_{6}$

$\left.\mathrm{b}_{(\mathrm{Ca}} 0.82{ }^{\mathrm{Na}} 0.03\right)_{0.85} \quad\left(\mathrm{Mg}_{1.02} \mathrm{Fe}_{0.12} \mathrm{Mn}_{0.01}\right)_{1.15} \quad\left(\mathrm{Ti}_{0.02}{ }^{\mathrm{Si}_{1.92}}\right.$ $\left.\mathrm{Al}_{0.06}\right)_{2.00} \mathrm{O}_{6}$

${ }^{\mathrm{c}}\left(\mathrm{K}_{0.03}{ }^{\mathrm{Na}} 0.45 \mathrm{Ca}_{0.52}\right)_{1.00}\left(\mathrm{Al}_{1.51} \mathrm{Fe}_{0.03}\right)_{1.54} \mathrm{Si}_{2.46} \mathrm{O}_{8}$

$\mathrm{d}\left(\mathrm{K}_{0.03}{ }^{\mathrm{Na}} 0.47 \mathrm{Ca}_{0.52}\right)_{1.02}\left(\mathrm{Al}_{1.54}{ }^{\mathrm{Fe}_{0.03}}\right)_{1.57} \mathrm{Si}_{2.44} \mathrm{O}_{8}$

According to the Rittman index $(\delta=4.3)$ and $\mathrm{Ku}-$ no diagram, the analyzed sample is a slightly alkaline basalt. Compositional analysis of two clinopyroxene phenocrysts from similar basalt fragments (Table 3 ) also confirms the alkaline nature of the basalts. One clinopyroxene sample belongs to salite-augite and the other to endiopside-augite (Poldervaart and Hess, 1951). On the basis of a similarity in optic properties between clinopyroxene throughout the volcaniclastic sandstones, we presume that most clinopyroxene phenocrysts are of the same type. A crystallization of a single pyroxene phase (without pigeonite or orthopyroxene), which is similar in composition to salite and contains high amounts of $\mathrm{Al}$ and $\mathrm{Ti}$, is typical of alkaline basalts rather than tholeiitic basalt (Deer et al., 1963). The labradoritic composition of the plagioclase (Table 3 ) shows good agreement with the rock type defined.

\section{CONCLUSIONS}

1. The data obtained although inconclusive, indicate an alkaline nature for the basic magma which produced most of the volcanic material.

2 . The abundance of hyaloclastitic material, persistent in the lower part of the volcaniclastic sandstone sequence, and numerous holocrystalline basalt fragments in its upper part suggest that an initial subaqueous stage of volcanic activity gave place to a more intense subaerial stage during the uplift of the Canary Islands.

\section{REFERENCES}

Deer, W. A., Howie, R. A., and Zussman, J., 1963. Rockforming minerals. Chain silicates: London (Longmans, Green \& Co.), v. 2.

Poldervaart, A. and Hess, H. H., 1951. Pyroxenes in the crystallization of basaltic magma, J. Geol., v. 59, p. 472 . 